Jin Xiaomei

Liaoning Academy of Agricultural Sciences, Shenyang

Wang Lan

Beijing Academy of Agrarian Sciences, Beijing

The article describes the cases of record soybean harvests of the variety Tszhun Khuan 35 obtained in different years in different areas. Influence of the factors contributing to the record yields - namely, variety, environmental conditions, growing technology - is analyzed. Physiological parameters of soybean plants were established, and a model for obtaining super yields was generated.

Soybean variety Tszhun Khuan 35, environmental conditions, growing technology, super yiled model

\title{
Introduction
}

The trials of the soybean variety Tszhun Khuan 35 in eight locations of Xinjiang (China) in 2008-2012 showed that the average yield over the study years was $381.0 \mathrm{~kg} / \mathrm{mu}(1 \mathrm{mu}=$ $0.15 \mathrm{ha}$ ), including the record yield in 2010 of $405.9 \mathrm{~kg} / \mathrm{mu}$. This record harvest was achieved through the best combination of three factors - variety / environmental conditions / growing technology.

Soybean plants of the variety Tszhun Khuan 35 belong to the intermediate growth type, have robust stems, leaves of medium size; pods grow uniformly densely. Lighting in Xinjiang is sufficiently intense, large differences in day and night temperatures contribute to biomass accumulation. The seeding rate is $20,000 / \mathrm{mu}$ (or 300,000 / ha). Several irrigations with fertilizers during the growing season provide the need of plants in water and nutrition.

It is known that the development of soybean, like other plants, depends on three factors variety, environmental conditions and growing technology, i.e., variety genotype, growing conditions (light, temperature, moisture content, nutrition) and an optimal technology.

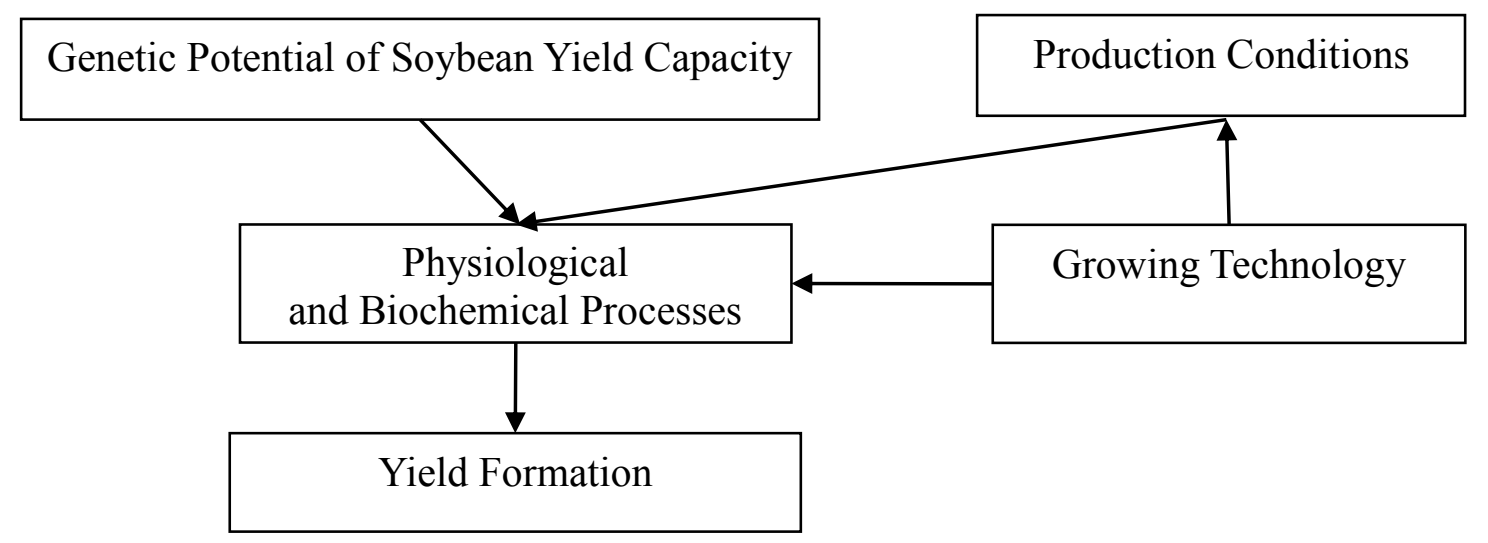

Figure 1. Factors of Soybean Yield Formation

It should be noted that all the three factors - variety, production conditions and growing technology are closely related; soybean production is impossible without one of them. Lack of one of the three factors had a negative impact on yield formation. 
Since the eighth five-year period (1991-1995) our state has approved a project to receive super yields in soybean growing areas. In the regions of Huang, Huai and Hai high yields were obtained - $300 \mathrm{~kg} / \mathrm{mu}$; in the North-Eastern region - $325 \mathrm{~kg} / \mathrm{mu}$, in the Southern region $250 \mathrm{~kg} / \mathrm{mu}$. It is noteworth that in the region of Xinjiang for several years running soybean yields exceeded $375 \mathrm{~kg} / \mathrm{mu}$, in particular the soybean variety Zhunkhuan 35 gave the highest yield over $400 \mathrm{~kg} / \mathrm{mu}$. Xinjiang Academy of Reclamation of Virgin and Fallow Lands, studying the soybean variety Zhun Khuan 35, received a record yield and determined physiological processes that contribute to this.

Study objective: analysis of the obtainment of the super yields in the soybean variety Zhun Khuan 35; investigation of mechanisms of this phenomenon for future breeding and generating models of cultivation technologies of high yields.

\section{Study results.}

1. Peculiarities of the soybean variety Zhun Khuan 35

The soybean variety Zhun Khuan 35 was bred at the Institute of Cultivated Plants of Chinese Academy of Agricultural Sciences. It is characterized by high potential yield capacity and wide adaptability, both in summer sowing in the Northern regions of Huang, Huai and Hai and in spring sowing in the Northern parts. Cultivation of this variety on the vast areas - from the Northern Liaoning Province to the Southern Anhun Province and the Western Xinjiang Province (latitude from $32^{\circ}$ to $45^{\circ}$ ) showed its stability and adaptability.

Plants of the soybean variety Zhun Khuan 35 belong to intermediate type of growth; bushes are compressed. The plant height is $90 \mathrm{~cm}$. With the seeding rate of 20,000/ mu their robust stems do not lodge. Leaves are oval, of medium size; bushes in the crop are well lit by the sun. Flowering is early; initiation of pods is low (they appear in the node of the first true leaf); pods are evenly arranged on the stem.

\section{Conditions of soybean yield formation.}

The soybean variety Zhunkhuan 35 has been grown in Xinjiang since 2008, where it has given record harvests many times.

If a record harvest of the soybean variety is produced only under certain conditions of cultivation, and in other areas it does not give high yields, it is considered a casuality. In different years and in different places the soybean variety Zhun Khuan 35 gave high yields under favorable conditions and cultivation technology, which means that the soybean variety Zhunkhuan 35 has a high yield potential.

The soybean variety Zhunkhuan 35 has given high yields eight times $(345.5-405.9 \mathrm{~kg} / \mathrm{mu})$, on average $381.5 \mathrm{~kg} / \mathrm{mu}$ (table 1$)$.

Table 1

Key Indices of the Soybean Variety Zhunkhuan 35 in the Region of Xinjiang

\begin{tabular}{|c|c|c|c|c|c|c|}
\hline $\begin{array}{c}\text { Yield, } \\
\mathrm{kg} / \mathrm{mu}\end{array}$ & Year & $\begin{array}{c}\text { Location of } \\
\text { growing }\end{array}$ & $\begin{array}{c}\text { Density of } \\
\text { stand, pcs/mu }\end{array}$ & $\begin{array}{c}\text { Plant } \\
\text { height, cm }\end{array}$ & $\begin{array}{c}\text { Number of pods, } \\
\text { pcs/plant }\end{array}$ & $\begin{array}{c}\text { Accounted } \\
\text { area, mu }\end{array}$ \\
\hline 364.5 & 2008 & ICP XARVFL & 18382 & 78.4 & 49.2 & 1.0 \\
\hline 371.8 & 2009 & ICP XARVFL & 18310 & 89.7 & 40.9 & 1.2 \\
\hline 389.3 & 2010 & XPCMU 148 & 15081 & 78.8 & 46.3 & 11.2 \\
\hline 364.7 & 2011 & XPCMU 148 & 20136 & 90.4 & 43.5 & 86.8 \\
\hline 399.0 & 2011 & XPCMU 148 & 20900 & 88.8 & 45.7 & 1.39 \\
\hline 354.5 & 2011 & XPCMU 148 & 18713 & 86.4 & 42.2 & $224(5$ plots $)$ \\
\hline 402.5 & 2011 & XPCMU 148 & 19557 & 90.1 & 36.4 & 1.19 \\
\hline 405.9 & 2012 & XPCMU 148 & 19950 & 114.5 & 40.5 & 1.07 \\
\hline $\begin{array}{c}\text { Average } \\
381.5\end{array}$ & - & - & 18879 & 89.6 & 43.1 & - \\
\hline
\end{tabular}

Footnote: ICP XARVFL - Institute of Cultivated Plants of Xinjiang Academy of Reclamation of Virgin and Fallow Lands

XPCMU 148 - Xinjiang Production and Construction Military Unit 148 
The studies showed that at the stand density of 20,000/ mu the plant height was $89.6 \mathrm{~cm}$, the number of pods per plant was 43.1 pcs., the seed weight per plant was $21 \mathrm{~g}$. Analyzing the factors of yield formation we can see that the record harvest in the soybean variety Zhunkhuan 35 depends not on performance of individual plants, but on density of stand. The density of stand in the variety Zhunkhuan 35 is two-fold in comparison with that in other varieties (the stand density in other varieties $-10,000 / \mathrm{mu}$ ).

Soybean harvest is estimated as product weight per area unit. Seed weight from a single plant is called performance. Therefore, increase in plant density per area unit is mandatory, and this increase is possible with a desired type of plants. The soybean variety Zhunkhuan 35 meets this requirement: plants are of medium height; leaves are medium sized; stems are sturdy; pods are evenly spaced on the main stem; branches are located at the top; pods in fours - sixes are located in the upper nodes.

Record soybean harvests in the variety Zhunkhuan 35 is closely associated with local conditions. According to statistics, in the region of Xinjiang solar radiation is of high intensity and reaches up to $5,300 \mathrm{~mJ} / \mathrm{m}^{2}$. From April to October (growing season), the sunlight period accounts for 1,300 hours. The sum of active temperatures reaches $2,900{ }^{\circ} \mathrm{C}$; difference between day and night temperatures is great, up to $12-15{ }^{\circ} \mathrm{C}$. This contributes to accumulation of plant biomass. Annual rainfall amount is $100 \mathrm{~mm}$, watering, if necessary, is carried out with melt water from the snow of Mount Shan Dian.

In Xinjiang soybean is grown with irrigation under exceptionally favorable natural conditions; the only source of energy for photosynthesis is sunlight. Adequate lighting stimulates chemical reactions of photosynthesis, synthesis of organic compounds, larger accumulation of energy and soybean biomass, and thereby, increasing in seed yield.

Regarding the third factor - production one- there are two important links: firstly, increase in planting density up to 20,000 / mu and obtainment of high yields in terms of plant weight per area unit; secondly, watering combined with top dressing.

One of the most important measures to provide high soybean yields under production conditions in the region of Xinjiang is watering. For example, in 2012 in the field of Xinjiang Production and Construction Military Unit 148 watering has been conducted 12 times throughout the growing season with $8.17-18.8 \mathrm{~m}^{3}$ of water (nonuniformly), with the total amount of $404.8 \mathrm{~m}^{3}$; together with irrigation top dressing with fertilizers has been performed: urea - ten times by $1-4 \mathrm{~kg} / \mathrm{mu}$, with the total amount of $29.2 \mathrm{~kg} / \mathrm{mu}$; potassium phosphate and ammonium phosphate - seven times by $1-2 \mathrm{~kg} / \mathrm{mu}$, with the total amount of $9.37 \mathrm{~kg} / \mathrm{mu}$; ammonium phosphate - nine times by $1-3.26 \mathrm{~kg} / \mathrm{mu}$, with the total amount of $20.25 \mathrm{~kg} / \mathrm{mu}$; iron sulfate - three times by $1-3,26 \mathrm{~kg} / \mathrm{mu}$, with the total amount of $5.89 \mathrm{~kg} / \mathrm{mu}$. In addition, extra nutrition with microfertilizers has been performed: three times by $3.31 \mathrm{~kg} / \mathrm{mu}$; and twice with zinc and manganese fertilizers, with the total amount of $1.15 \mathrm{~kg} / \mathrm{mu}$. Fertilizing together with watering and repeated dressings with small doses not only covered needs of plants in water and nutrients, but also reduced their losses. As support actions, spraying with paclobutrazol at the dose of $78.3 \mathrm{~g} / \mathrm{mu}$ in the phase of mass flowering has been conducted five times, with substance "Sho Jie An" shortening internode length at the dose of $31 \mathrm{~g} / \mathrm{mu}$ - five times, and with the growth stimulator "Ai Mi Ting" at the dose of $0.66 \mathrm{~g} / \mathrm{mu}$ - twice.

Thus, environmental conditions in the region of Xinjiang, provided that crops were thickened, in combination with watering and fertilizing promoted expression and development of the yield potential in the soybean variety Zhun Khuan 35.

3. Physiological parameters of soybean plants of the variety Zhunkhuan 35 for obtainment of record yields.

Leaf Area Index (LAI).

Leaf area index is the ratio of leaf area to crop area unit. LAI magnitude depends on the number of plants and degree of their development. In the studies $[1,2]$ it was found that when 
the yield was high, LAI was 5-6 and closely correlated with biomass $(r=0.974)$ and seed yield $(\mathrm{r}=0.860)$. The researcher Wei Jianjun in his trials [3] in the region of Xinjiang demonstrated that the maximum LAI in the soybean variety Zhun Khuan 35 amounted to 4.31 (determined 72 days after sowing, in phase R3), the period with LAI> 3 was 50 days. The seed yield in this case amounted to $371.8 \mathrm{~kg} / \mathrm{mu}$. This proves that to obtain high yields it is not necessary to have LAI of 5-6; LAI higher than 3 for a long time is sufficient.

3.2 Photosynthetic potential (LAD) of the soybean variety Zhun Khuan 35.

Leaf area duration (LAD) is very important. There are correlations between LAD and biomass - 0.968, between LAD and seed yield - 0.838. During the growing season of the soybean variety Te Fen $18 \mathrm{LAD}$ was $205,880 \mathrm{~m}^{2}$ per day/mu, and the yield in this case was $242 \mathrm{~kg} / \mathrm{mu}$ [2]. Wei Jianjun et al. [4] in their studies showed that with the seed yield of the soybean variety Zhun Khuan 35 of $371.8 \mathrm{~kg} / \mathrm{mu}$ LAD totaled $184,430 \mathrm{~m}^{2}$ per day/mu. This indicates that the photosynthesis efficiency in the soybean variety Zhun Khuan 35 in the region of Xinjiang is higher than that in the soybean variety Te Fen 18 in Liaoning Province. In the soybean variety Zhun Khuan $35 \mathrm{LAD}$ of $496 \mathrm{~m}^{2}$ per day/mu produces the seed yield of $1 \mathrm{~kg}$, while in the soybean variety Te Fen 18 the seed yield of $1 \mathrm{~kg}$ is formed by LAD of $855 \mathrm{~m}^{2}$ per day/mu.

3.3 Net photosynthetic productivity in the soybean variety Zhunhuan 35 .

To evaluate the efficiency of photosynthesis the net photosynthetic productivity was used, i.e., the daily accumulation of dry biomass by soybean leaf area unit $\left(\mathrm{g} / \mathrm{m}^{2}\right.$ per day). Many researchers proved that the soybean seed yield did not depend on the average NPP throughout the growing season, there was no correlation between them (Watson, 1952; LT Evans, 1975; Cooper, 1976; Nichiporrovich AA, 1979; Dun Zhang, 1979).

However, Gunzhu Zhang's (1979) and Fu Tszinmin's [5] studies showed that in the period of flowering - seed filling there were correlations between NPP and biomass, NPP and seed yield. Wei Jianjun et al. [4] demonstrated this relationship in their work, analyzing the soybean variety Zhun Khuan 35, more specifically, they found a positive correlation between NPP and seed yield 72 - 114 days after sprouting (table 2).

Table 2

Distribution of net photosynthetic productivity across developmental stages, $\mathrm{g} / \mathrm{m}^{2}$ per day, and soybean seed yield

\begin{tabular}{|c|c|c|c|c|c|c|c|c|c|c|c|}
\hline \multirow{2}{*}{ Variant } & \multicolumn{7}{|c|}{ Days after sprouting } & \multirow{2}{*}{$\begin{array}{c}\text { Yield, } \\
\mathrm{ng} / \mathrm{mu}\end{array}$} \\
\cline { 2 - 13 } & 16 & 30 & 44 & 58 & Mean & 72 & 86 & 100 & 114 & Mean & \\
\hline Zhun Khuan 35 & 8 & 4.2 & 5.2 & 3.3 & 4.1 & 2.5 & 4.0 & 5.0 & 2.7 & 3.6 & 368.1 \\
\hline Sindadou 1 & 3.8 & 6.0 & 4.7 & 4.3 & 4.7 & 0.7 & 2.9 & 3.5 & 0.6 & 1.9 & 311.1 \\
\hline
\end{tabular}

16-58 days after sprouting NPP in the variety Zhun Khuan 35 (mean 4.1) was slightly lower than that in the variety Sindadou 1 (mean 4.7), but after 72-114 days after sprouting NPP of Zhun Khuan 35 (mean 3.6 ) was conversely higher than that in the variety Sindadou 1 (mean 1.9) (table. 2). This indicates that high NPP in the phase of flowering - seed filling provides high yields in the variety Zhun Khuan 35.

3.4 Balance between Soybean Plant Organs.

Balance between soybean plant organs is a specific distribution of biomass formed by plants during the growing season, in plant organs. It is called balance of plant organs [2].

As a result of long-term studies of local soybean varieties in Liaoning Province it was discovered that percentage of biomass in plant parts - leaves, petioles, stems, pod shells, and seeds should correspond to $30 \%, 10 \%, 20 \%, 10 \%, 30 \%$, respectively. This is the theory of balance of soybean plant organs. 
According to this theory, the researcher Wei Jianjun et al. [4], analyzing the soybean variety Zhun Khuan 35, determined the following balance: $16.6 \%$ in leaves, $9.4 \%$ in petioles, $14.8 \%$ in stems, $19.6 \%$ in pod shells, and $39.6 \%$ in seeds. Biomass of vegetative organs - leaves, petioles, stems - was lower than the theoretical distribution, and biomass of reproductive organs pods, seeds - much higher.

Over the five years of cultivation of the soybean variety Zhun Khuan 35 in the region of Xinjiang we not only got record harvests, but also supplemented materials on conditions for obtaining super yields. In future this will provide physiological parameters of soybean varieties, ensuring formation of high yield capacity.

\section{Список використаних джерел}

1. Wang L-Z. High yield soybean cultivar Zhonghuang 13 / L-Z. Wang, R-J. Zhao // Bull Agric Sci Technol. - 2005. - № 6. - 40 p. (на китайском языке).

2. Dong Z. Soybean Yield Physiology / Dong Z. - Beijing: China Agriculture Press, 2001. - P. 46-49 (на китайском языке).

3. Wei J-J. Physiological Parameters of Super-High Yielding Soybean Cultivar Zhonhuang 35 / J-J. Wei, G-T. Luo, L. Zhang // Acta Agronomica Sinca. - 2009. - № 35(3). - P. 506-511 (на китайском языке).

4. Zhang $R$-G. The relevance of the soybean leaf area, the net photosynthetic rate and yield / RG. Zhang, Y. Song // Sin Agric Sci. - 1979. - № 12(2). - P. 40-46 (на китайском языке с англоязычным резюме).

5. Fu J-M. Study on the photosynthetic characters of summer soybean canopy / J-M. Fu // Soybean Science. - 1994. - № 13(1). - P. 16-21 (на китайском языке).

\section{References}

1. Wang L-Z, Zhao R-J. High yield soybean cultivar Zhonghuang 13. Bull Agric Sci Technol. 2005; 6:40.

2. Dong Z. Soybean Yield Physiology. Beijing: China Agriculture Press; 2001. P. 46-49.

3. Wei J-J, Luo G-T, Zhang L. Physiological parameters of super-high yielding soybean cultivar Zhonhuang 35. Acta Agronomica Sinca. 2009; 35(3):506-511.

4. Zhang R-G, Song Y. The relevance of the soybean leaf area, the net photosynthetic rate and yield. Sin Agric Sci. 1979; 12(2):40-46.

5. Fu J-M. Study on the photosynthetic characters of summer soybean canopy. Soybean Science. 1994; 13(1):16-21. 
Цзинь Сяомей

Ляонініська академія аграрних наук, м. Шеньян

Вань Лан

Пекінська академія аграрних наук, м. Пекін

У статті розглянуто приклади одержання рекордної урожайності сої сорту Цжуан Хуан 35.

Мета. Аналіз випадків рекордної урожайності (понад 400 кг/му, або 2,8 т/га), дослідження механізмів цього явища та створення моделі технології вирощування таких урожаїв.

Умови проведення досліджень. Сорт сої Цжуан Хуан 35 у 2008-2012 рр. вирощували у восьми пунктах різних природних зон Китаю. Норма висіву складала 20 тис./му (300 тис./га), впродовж вегетації проводили декілька поливів разом із підживленням.

Результати. Для одержання рекордної урожайності сої необхідним є оптимальне поєднання трьох факторів - сорт / екологічні умови / технологія вирощування. Сорт Цжуан Хуан 35 характеризується як високо адаптивний з високою потенційною урожайністю. Стійкий проти вилягання, листочки середнього розміру, що сприяє хорошому освітленню сонцем усього посіву. Ці сортові особливості сприяють успішному вирощуванню Цжуан Хуан 35 у загущеному посіві.

Екологічні умови в зонах вирощування також є сприятливими для одержання рекордної

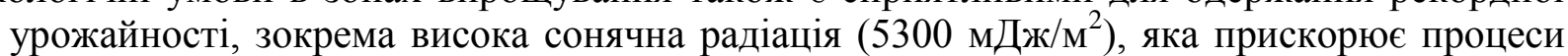
фотосинтезу і тим самим - синтез органічних сполук, накопичення біомаси у сої.

Окрім загущення посіву, на одержання високих урожаїв впливає полив разом із підживленням, а саме - 12 поливів із внесенням добрив і мікродобрив у невеликих дозах. До того ж, рослини сої обробляли препаратом «Шо Цзе Ань», який скорочує довжину міжвузлів та стимулятором росту «Ай Мі Тін».

Досліджено вплив фізіологічних параметрів, зокрема індексу листової поверхні (LAI), фотосинтетичного потенціалу (LAD), чистої продуктивності фотосинтезу, балансу органів рослини.

Висновки. У результаті досліджень встановлено, що одержанню рекордної урожайності сої сорту Цжуан Хуан 35 сприяють його морфологічні особливості (стійкість проти вилягання, толерантність до загущення), екологічні умови (висока сонячна радіація, різниця денних і нічних температур), елементи технології вирощування (багаторазовий полив з підживленням у невеликих дозах, використання стимулюючих препаратів), фізіологічні параметри рослин сорту Цжуан Хуан 35. Так, баланс органів рослин як питомий розподіл біомаси у сорту Цжуан Хуан 35 складає 16,6 \% у листках, 9,4 \% у черенках листків, 14,8 \% у стеблах, 19,6 \% у стулках бобів 39,6 \% і в насінні на відміну від теоретичного $30 \%, 10 \%, 20 \%, 10 \%, 30 \%$ відповідно. Таким чином, біомаса вегетативних органів - листків, черенків листків, стебел - була меншою за теоретичний розподіл, а репродуктивних органів - бобів, насіння - набагато більшою. Така особливість сорту сої Цжуан Хуан 35 є однією з причин одержання рекордної урожайності.

$$
\begin{gathered}
\text { сорт сої Цжуан Хуан 35, екологічні умови, технологія вирощування, } \\
\text { модель надурожайності }
\end{gathered}
$$

\section{CASE STUDIES OF SUPER YIELD IN THE SOYBEAN VARIETY TSZHUN KHUAN 35}

Jin Xiaomei

Liaoning Academy of Agricultural Sciences, Shenyang

Wang Lan

Beijing Academy of Agrarian Sciences, Beijing

The article discusses examples of record soybean yields in the variety Tszhuan Khuan 35 .

Objective. Analysis of cases of record yields (over $400 \mathrm{~kg} / \mathrm{mu}$, or $2.8 \mathrm{t} / \mathrm{ha}$ ), investigation of mechanisms of this phenomenon and creation of a cultivation technology model of such harvests. 
Study Conditions. In 2008-2012 the soybean variety Tszhuan Khuan 35 was grown in eight different locations of natural zones of China. The seeding rate was 20,000 / mu (300,000 / ha). Several irrigations with top dressing were conducted during the growing season.

Results. To obtain record soybean yields the optimal combination of three factors is necessary variety / environmental conditions / growing technology. The variety Tszhuan Khuan 35 is characterized as a highly adaptive one with high potential yield capacity. It is resistant to lodging, with leaves of medium size contributing to good sun lighting of the whole crops. Such varietal features contribute to successful cultivation of Tszhuan Khuan 35 in thickened crops.

Environmental conditions in growing areas are also favorable for record yields, in particular, high solar radiation $\left(5,300 \mathrm{~mJ} / \mathrm{m}^{2}\right)$, which accelerates processes of photosynthesis, and, therefore, synthesis of organic compounds and accumulation of biomass in soybean.

In addition to thickening crops high yields are affected by watering with dressing, more specifically, 12 irrigations with fertilizers and micronutrients in small doses. Besides, soybean plants were treated with the preparation "Shou Jie An" shortening internode length and the growth stimulator "Ai Mi Ting".

The influence of physiological parameters was assessed, in particular leaf area index (LAI), photosynthetic potential (LAD), net photosynthetic productivity, and balance of plant organs.

Conclusions. The studies found that the achievement of record soybean yields in the variety Tszhuan Khuan 35 was promoted by its morphological peculiarities (resistance to lodging, tolerance to thickening), environmental conditions (high solar radiation, difference between day and night temperatures), elements of cultivation technology (multiple watering with dressing in small doses, stimulators), and physiological parameters of plants of the variety Tszhuan Khuan 35. Thus, the balance of plant organs as a specific distribution of biomass in the variety Tszhuan Khuan 35 is the following: $16.6 \%$ in leaves, $9.4 \%$ in petioles, $14.8 \%$ in stems, $19.6 \%$ in pod shells, and $39.6 \%$ in seeds, unlike the theoretical values of $30 \%, 10 \%$, $20 \%, 10 \%$, and $30 \%$, respectively. Therefore, the biomass of vegetative organs - leaves, petioles, stems - was lower than the theoretical distribution, and the biomass of reproductive organs - pods, seeds - much higher. This peculiarity of the soybean variety Tszhuan Khuan 35 is one of the causes of record yields.

Soybean variety Tszhuan Khuan 35, environmental conditions, cultivation technology, model of super yield capacity 